er således ikke først at fremmest at forstå som en »fænomenologi om den menneskelige frihed, men [...] en ontologi for den oprindelige frihed, der udgør virkelighedens og eksistensens begyndelse« (s. 31). Det kan ikke lade sig gøre at yde retfærdighed mod Pareysons komplekse argumenter for sin personalisme hér, men Pareysons synspunkter er ganske givet ikke blevet mindre aktuelle, efterhånden som flere filosoffer (bl.a. Hutter, Hogrebe og allerede nævnte Gabriel og Žižek) i de senere år synes at have genoptaget Schelling.

Jens Viggo Olavi Nielsens omfattende, grundige og samvittighedsfulde "Efterord" er helt afgjort også værd at læse. Det er desuden bemærkelsesværdigt, hvordan Olavi Nielsen her lægger sig grundigt ud med den anden af Danmarks bedst kendte Pareysonfortolkere, nemlig Søren Gosvig Olesen.

Kresten Lundsgaard-Leth

\title{
Tilbage til fremtiden - et pragmatisk værks mystiske genkomst
}

\author{
Jobn Dewey: \\ Unmodern Philosophy and Modern Philosophy, \\ Southern Illinois University Press, \\ 2012, 352 sider, 60,00 USD.
}

Da han var i begyndelsen af firserne, midt under 2. verdenskrig, påbegyndte den nok største af de klassiske amerikanske pragmatister, John Dewey (1859-1952), et værk som skulle opsummere hans livsværk og udgøre "en 'social' fortolkning af filosoffers, hvis ikke filosofiens, historie" - en filosofiens kulturhistorie. Men da manuskriptet næsten var færdigt slog skæbnen til og i noget som minder om en scene fra en ikke helt troværdig film glemte Dewey det i en taxa hvorefter han aldrig så det igen og opgav at begynde forfra. Siden hans død har Dewey-interesserede forskere naturligt nok spekuleret over hvad indholdet af denne bog ville have været og om den ville have rummet nye, interessante tanker. Men samtidig har de også været bevidste om at det selvfølgelig var en håbløs og nytteløs 
spekulation og fantasi - for manuskriptet eksisterede jo ikke mere, det var forsvundet. Troede man. For på mystisk vis dukkede det for et par år siden op i Dewey-arkivet ved University of Southern Illinois, Carbondale, fundet af den unge Dewey-forsker Phillip Deen. Det er også Deen som har redigeret manuskriptet og stået for udgivelsen af det som en 350 sider stor bog (med den lidet elegante titel "Unmodern Philosophy and Modern Philosophy") samt skrevet en veloplagt introduktion som dels beskriver manuskriptets mystiske historie (man ved endnu ikke hvordan det er havnet i arkivet) og dels redegør for bogens forskellige kapitler og relaterer værket til Deweys omfattende oeuvre og det 20. århundredes filosofihistorie mere generelt.

Og der er al mulig grund til at være Deen dybt taknemmelig for at have udført dette arbejde. For på trods ad den uelegante titel og manuskriptets tumultariske historie, så er teksten forbavsende elegant og kan snildt måle sig med Deweys bedste værker. Der mangler lidt interne referencer hist og her og det er ikke et værk med et afrundende, kulminerende kapitel som man kender det fra hans andre bøger, men selve teksten og tankerne er fuldt på højde med Dewey når han er bedst. Stilen er let tilgængelig og åbenlyst rettet mod et bredere publikum sådan så bogen nok minder mest om hans Reconstruction in Philosophy fra 1920. Indholdsmæssigt består den af to dele, hvor den første del over syv kapitler udfolder en filosofiens kulturhistorie helt tilbage fra før før-sokratikerne til i dag, mens den anden del, ligeledes over syv kapitler, udfolder Dewey's egne tanker om hvad filosofien kan og bør gøre i dag.

Grundtanken bag hele projektet er velkendt fra Deweys mange andre skrifter og $i$ den forstand indeholder bogen ikke noget radikalt nyt: filosofi og tænkning $i$ almindelighed opstår på grund af sociale og kulturelle spændinger og konflikter. Men forskellige måder at tænke på kan blive så indgroede at de vedbliver med at styre folks tanker efter at de sociale og kulturelle betingelser som oprindeligt motiverede dem er forsvundne og erstattet af nye sociale og kulturelle forhold og konflikter i forhold til hvilke de tidligere måder at tænke på er mere og mere irrelevante. Det er også dette Dewey så som filosofiens største fare, hvis den blev ved med at beskæftige sig med de traditionelle filosofiske problemer (især de såkaldt 'epi- 
stemologiske' problemer) i stedet for aktuelle sociale og kulturelle problemer og konflikter: at den ville blive mere og mere irrelevant. En profeti som nok godt kan siges at være blevet bekræftet af historiens gang hvad angår store dele af filosofien. Deweys håb var at en filosofiens kulturhistorie, som viser hvordan bestemte filosofiske problemer opstår under bestemte sociale og kulturelle forhold, kan overbevise filosoffer om at en lang række af de problemer som de bruger deres tid på at 'løse' simpelthen er irrelevante i forhold til de eksisterende sociale og kulturelle forhold - megen moderne filosofi er i den forstand håbløst umoderne (jf.titlen).

Selv om grundstrukturen altså er helt genkendelig fra Deweys andre værker er der dog så mange variationer og friske perspektiver i udarbejdelsen og detaljen at kendere af Dewey også vil kunne læse bogen med stort udbytte. Første dels andet kapitel, "The Story of Nature", byder således fx på et nyt og detaljeret forsøg på at forklare hvordan der i antikkens Grækenland opstod to forskellige ideer om naturen, physis, som henholdsvis vækst og manipulerpart materiale $\mathrm{i}$ forhold til to forskellige former for sociale forhold, erfaringer og praksisser - $\mathrm{i}$ det ene tilfælde domineret af landbrug og i det andet tilfælde domineret af håndværk. Der er også et interessant kapitel som diskuterer grækernes opdagelse af logos og måden hvorpå de projekterede denne opdagelse af fornuften og sproget ud på naturen, så naturen blev opfattet som legemliggjort grammatik.

Det er dog nok bogens anden del med fem central kapitler, der hver især indgående behandler klassiske filosofiske distinktioner så som ting og person, sjæl og legeme, praktisk og teoretisk, materiel og ideel, natur og menneske, som en nutidig læser vil finde mest interessant. Og her er det måske særligt behandlingen af viden, som viser at Dewey's filosofi må siges at have stået distancen og stadigvæk må anses for relevant idag på trods af den enorme udvikling i sociologiske og historiske studier af viden, som har fundet sted siden hans død. Med udgangspunkt i en præmis om at "det som vi forsøger at gøre med viden er dybt påvirket af det som vi tror viden er" (p. 145) udfolder han således et alternativt filosofisk syn på viden, som fører til følgende ide om hvad det vil sige at tale om kendsgerninger:

"At tage en begivenhed som en kendsgerning er at tage den ud 
af en kaotisk og stum anonymitet og given den offentlig rang og status. Det er at betegne den som et medlem af en specifik orden stående i bestemte forbindelser med andre medlemmer af denne orden. For det at kalde noget som helst en kendsgerning er at tilskrive det et berettiget krav på og autoritet til at bestemme overbevisninger og til at afgøre hvilke konklusioner som skal drages inden for et givent felt" (p. 137).

I forængelsen heraf ser Dewey eksplicit videnskabeligt materiale som "en social begivenhed blandt andre" (p. 149) og denne forståelse af viden som intimt forbundet med social magt og autoritet fører direkte til værkets centrale vidneskabsfilosofiske påstand om at "den nutidige filosofis mest presserende opgave er at indikere videns plads og funktion som en retmæssig social magt og autoritet $i$ bestemmelsen af andre social relationer" (p. 163). I resten af værket udfoldes denne ide så grundigt og detaljeret fra en række forskellige perspektiver og med et væld af overrumplende og tankevækkende betragtninger, som alt $i$ alt gør bogen til en udsøgt fornøjelse at læse og får denne anmelder til varmt at anbefale den til såvel nytilkommere som kendere af Deweys pragmatisme. Der findes næppe et bedre sted at begynde - eller at slutte.

Martin Ejsing Christensen 